\title{
In Vitro Ruminal Fermentation Using Inoculum From Chamois and Cattle
}

\author{
A. Dalmau, ${ }^{1}$ A. Ferret, ${ }^{2}$ X. Manteca, ${ }^{2}$ and S. Calsamiglia ${ }^{2}$ \\ Authors are ${ }^{1}$ Ph.D. student, and ${ }^{2}$ full professors, Veterinarian School, \\ Universitat Autònoma de Barcelona, 08193 Bellaterra, Spain.
}

\begin{abstract}
Six dual-flow continuous culture fermenters were used over a 10-day experimental period to compare the digestibilities of dry matter (DM) and fiber, ruminal fermentation profile, and nitrogen metabolism of rumen microbial populations obtained from an inoculum of chamois (Rupicapra pyrenaica pyrenaica) and cattle (Bos taurus). The aim of this work was to test the fermenters with inoculum from chamois and to compare the function of ruminal microbial population of chamois and cattle under the same conditions of diet and passage rate. Fermenters were fed $56 \mathrm{~g}$ DM daily of a diet consisting of $75 \%$ Italian ryegrass hay (Lolium multiflorum Lam. var. westerwoldicum) and $25 \%$ alfalfa hay (Medicago sativa L.). Both inocula were adapted to the in vitro conditions after 6 days. There were no differences in DM and fiber digestibilities, and total volatile fatty acids concentration (VFA) between cattle and chamois inocula. The proportion of propionate was higher (25.8 vs. $17.9 \mathrm{~mol} / 100 \mathrm{~mol})$, and that of butyrate was lower ( 9.9 vs. $13.8 \mathrm{~mol} / 100 \mathrm{~mol}$ ) in chamois inoculum than in cattle inoculum. Ammonia nitrogen concentration was greater $(10.6$ vs. $6.7 \mathrm{mg} / 100 \mathrm{ml})$, but microbial protein synthesis was lower $(41.1 \mathrm{vs} .55 .3 \%$ of total nitrogen flow) in chamois inoculum than in cattle inoculum. These results suggest that microbial populations from chamois and cattle inocula, maintained under the same conditions of diet and passage rate, have a similar degradation capacity, producing the same amounts of VFA, but with a different fermentation profile, and different microbial protein synthesis. The dual-flow continuous culture fermenters could be a useful tool to study ruminal fermentation in wild species such as Pyrenean chamois.
\end{abstract}

\section{Resumen}

Durante 10 días se utilizaron 6 fermentadores de un sistema de cultivo continuo de doble flujo para comparar las digestibilidades de la materia seca (MS) y la fibra, el perfil de fermentación ruminal y el metabolismo del nitrógeno de poblaciones microbianas ruminales obtenidas de un inóculo de rebeco (Rupicapra pyrenaica pyrenaica) y vaca (Bos taurus). Los objetivos del trabajo eran probar los fermentadores con inóculo de rebeco, y comparar la función de las poblaciones microbianas ruminales de un rebeco y de una vaca al estar sometidas a las mismas condiciones de dieta y ritmo de paso. Los fermentadores se alimentaban diariamente con $56 \mathrm{~g}$ MS de una dieta formada en un $75 \%$ por heno de Ryegrass italiano (Lolium multiflorum Lam. var. westerwoldicum) y en un $25 \%$ por heno de alfalfa (Medicago sativa L.). Ambos inóculos se adaptaron a las condiciones in vitro a partir del sexto día. No hubo diferencias entre inóculos en las digestibilidades de la fibra y de la MS, así como en la concentración total de ácidos grasos volátiles (AGV). La proporción de propionato fue más alta (25,8 vs. 17,9 mol/100 mol), y la de butirato más baja (9,9 vs. $13,8 \mathrm{~mol} / 100 \mathrm{~mol}$ ) en el inóculo de rebeco que en el de vaca. La concentración de nitrógeno amoniacal fue más alta (10,6 vs. 6,7 $\mathrm{mg} / 100 \mathrm{ml}$ ) y la síntesis de proteina microbiana más baja (41,1 vs. 55,3\% del flujo total de nitrógeno) en el inóculo de rebeco que en el de vaca. Estos resultados sugieren que las poblaciones microbianas ruminales de rebeco y vaca, mantenidas bajo las mismas condiciones de dieta y ritmo de paso, tienen una capacidad de degradación similar, produciendo parecidas cantidades de AGV, pero con un perfil de fermentación distinto, y menor síntesis de proteina microbiana. El sistema de fermentadores de cultivo continuo de doble flujo aparece como una herramienta útil para estudiar la fermentación ruminal en especies salvajes como el rebeco pirenaico.

Key Words: dual-flow continuous culture, fermentation profile, nitrogen metabolism

\section{INTRODUCTION}

Cattle (Bos taurus) and the Pyrenean chamois (Rupicapra pyrenaica pyrenaica) are in the suborder Ruminantia. The Pyrenean chamois is a mountain-dwelling ungulate with a high selective character when feeding (Catusse et al. 1996). According to the morphophysiology of the digestive tract, chamois was classified by Hofmann (1988) as an intermediate eater. The

Correspondence: A. Ferret, Ciència Animal i dels Aliments Dept, Veterinarian School, Universitat Autònoma de Barcelona, 08193 Bellaterra, Spain. Email: alfred.ferret@uab.es

Manuscript received 21 July 2004; manuscript accepted 28 February 2006. intermediate eaters are species adapted to mixed diets, although these species usually avoid fiber as long and as much as possible. At the same time, intermediate eaters show remarkable short-term or seasonal anatomical adaptations to changes in forage quality (Hofmann 1988). In contrast, cattle are classified as grass and roughage eaters, with a low selective character (Hofmann 1988). The body weight of most female cattle ranges from 450 to $650 \mathrm{~kg}$, while the body weight of Pyrenean chamois ranges from 25 to $45 \mathrm{~kg}$. Conventional expression of animal requirements assumes that energy requirements are proportional to metabolic body weight, meaning that small animals require more feed per unit of body weight for maintenance than larger animals. Nevertheless, the digestive tract 
size is proportional to body weight. In consequence, small herbivores select more nutritious and easily digestible concentrate feeds, eat more frequently, and have a greater passage rate compared with larger species (Van Soest 1994). Moreover, fiber digestibility is considered to be lower in intermediate eaters than grazing ruminants adapted to roughage diets (Arman and Hopcraft 1975; Milne et al. 1978). Few data exist examining the probable differences in the fermentative activity of the microbial populations between chamois and cattle. Therefore, an in vitro rumen microbial fermentation experiment, with the same diet and fermentation conditions, was designed with the aim of comparing the activity of rumen microbial populations in chamois and cattle. The hypothesis of this study was that in the absence of intrinsic differences between the two species, such as diet selection or passage rate, two ruminal populations randomly taken from one individual of each species should show similar capabilities to digest the diet after a period of adaptation. At the same time, the adaptation period of this experiment was studied with the objective to test the continuous fermentation in vitro system used for species such as Pyrenean chamois for further studies and management purposes.

\section{METHODS}

\section{Inoculum and Continuous Culture System}

A continuous fermentation in vitro system was used to compare ruminal microbial activity in cattle and chamois. Inocula were obtained from a lactating Holstein cow (body weight $650 \mathrm{~kg}$ ) fitted with a permanent ruminal cannula and from a male adult chamois (body weight $25 \mathrm{~kg}$ ) hunted in the wild. The cow was fed on a libitum basis with 50 to 50 forage to concentrate diet (17\% crude protein [CP]; 31\% neutral detergent fiber [NDF]; and $20 \%$ acid detergent fiber [ADF] $)$. The diet, on a dry matter (DM) basis, consisted of alfalfa hay $(49.4 \%)$, ground barley grain $(24.4 \%)$, ground corn grain $(15.4 \%)$, soybean meal $(9.7 \%)$, white salt $(0.3 \%)$, monobasic sodium phosphate $(0.4 \%)$, and a vitamin and mineral mixture $(0.4 \%)$. The chamois was hunted in the Cadi Hunting Reserve, in the North-east of Spain (lat $42^{\circ} 15^{\prime} \mathrm{N}$, long $1^{\circ} 41^{\prime} \mathrm{E}$ ). The predominant vegetation in the zone was Pinus mugo Turra subsp. uncinata Ramond, woods and areas with bushes such as Juniperus communis subsp. nana Willd., Rhododendron ferrugineum L., and Arctostaphylos uva-ursi (L.) Spreng. Festucetum scopariae, a plant community typical of the subalpine calcareous slopes of the Cadi range, was also present in the zone. The main species are Festuca gauteri (Hackel) K. Richt., F. indigesta Boiss. subsp. durissima Hackel, Avena montana Vill., Poa alpina L., and Sesleria coerulea (L.) Ard. subsp. coerulea (Folch 1981). At higher altitudes, and probably too far away for the hunted chamois to reach, there were alpine meadows covered with a great variety of graminous plants, Festuca airoides Lam. being the predominant one, and other plants such as Gentiana acaulis L. subsp. alpina Vill. or Androsace carnea L. (Gurri 1997). In the case of chamois, ruminal fluid was obtained immediately after hunting by pressing the whole rumen content by hand and straining it through 2 layers of cheesecloth. It was collected in a prewarmed insulated container to ensure that its temperature did not drop below $30^{\circ} \mathrm{C}$, and then delivered to the laboratory 2.5 hours later. The $\mathrm{pH}$ of inoculum just after collection was 6.6 , and 6.8 when it arrived at the laboratory, 2.5 hours later. In the case of cattle the ruminal inoculum was randomly selected throughout the permanent ruminal cannula. The $\mathrm{pH}$ of cattle inoculum in the laboratory was 6.6.

Six dual-flow continuous-culture fermenters developed by Hoover et al. (1976) were used. Three fermenters were randomly assigned to cattle and three to chamois rumen fluid. Each fermenter consisted of a $1320-\mathrm{mL}$ flask, the contents of which were magnetically stirred at $300 \mathrm{rpm}$ and heated by a thermostatically controlled element. Each flask was equipped with a buffer input, a thermister probe, a $\mathrm{pH}$ probe, acid/base infusion pumps, and an input for nitrogen gas. Each flask had an overflow port to maintain volume. The effluent was collected in an effluent collection vessel. Buffer solution (artificial saliva) was pumped continuously into the fermenter flask by a peristaltic pump at a rate of $10 \%$ of the total volume per hour. The mineral buffer solution was prepared according to Weller and Pilgrim (1974), with the addition of $\mathrm{MgSO}_{4} \cdot 7 \mathrm{H}_{2} \mathrm{O}(0.12 \mathrm{~g} / \mathrm{L})$, and $0.4 \mathrm{~g} / \mathrm{L}$ of urea to simulate nitrogen recycling. In addition to the overflow port, each fermenter flask was equipped with a filter connected to a peristaltic pump that pumped the filtered digesta into another effluent collection vessel at a rate of $5 \%$ of the total volume per hour. In consequence, liquid and solids dilution rates were maintained at $10 \%$ and $5 \%$ per hour, respectively. Filters had a pore size of $0.14 \mathrm{~mm}$.

The $\mathrm{pH}$ was maintained between 6.2 and 6.8 by the infusion of $3 \mathrm{~N} \mathrm{HCl}$ or $5 \mathrm{~N} \mathrm{NaOH}$ solutions. Temperature was maintained at $39^{\circ} \mathrm{C}$. Fermenters were continuously infused with $\mathrm{N}_{2}$ at a rate of $40 \mathrm{~mL} / \mathrm{min}$ to ensure anaerobic conditions. Fermentation parameters were monitored and controlled by a Personal Computer and a Programmable Linear Controller (FieldPoint, National Instruments, Austin, TX). Fermentation conditions were programmed with Lab View Software (National Instruments).

Fermenters were fed 3 times a day, at 0800, 1600, and 2400 hours, with $56 \mathrm{~g}$ DM daily. Diet consisted of $75 \%$ Italian ryegrass hay (Lolium multiflorum Lam. var. westerwoldicum) and $25 \%$ alfalfa hay (Medicago sativa L.) ground using a $1 \mathrm{~mm}$ screen. The diet contained $96.0 \%$ of DM, and $88.9 \%$ of organic matter, $16.2 \%$ of CP, $2.3 \%$ of ether extract, $44.9 \%$ of NDF, and $25.8 \%$ of ADF, on DM basis. The diet CP concentration was chosen as an average CP concentration of the diet fed to the donor cow and the CP content of the grassland where the chamois was hunted. The latter was determined as the percentage of nitrogen in forage, in different zones of the reserve in September, when the chamois was hunted.

\section{Sample Collection}

The experimental period consisted of 9 days, 6 days for adaptation and 3 days for sample collection. Throughout the experiment, $16 \mathrm{~mL}$ of filtered fermenter fluid were taken 2 hours after the morning feeding to evaluate day to day changes in ruminal ammonia nitrogen $\left(\mathrm{NH}_{3}-\mathrm{N}\right)$ and volatile fatty acid (VFA) concentrations in each fermenter. During the sampling period, effluent collection vessels were maintained in a $4^{\circ} \mathrm{C}$ bath to prevent microbial action. Solid and liquid effluents were homogenized, and a $500 \mathrm{~mL}$ sample was removed by aspiration. Effluents from the 3 sampling days were composited and 
mixed within the fermenter. Three subsamples of mixed effluent were taken; 2 of them were acidified to deproteinise them with either $\mathrm{HCl}(4 \mathrm{~mL}$ effluent in $4 \mathrm{~mL} 0.2 \mathrm{~N} \mathrm{HCl})$ or $\mathrm{H}_{3} \mathrm{PO}_{4}(4 \mathrm{~mL}$ effluent in $1 \mathrm{~mL} 0.2 \% \mathrm{ClHg}, 2 \% \mathrm{H}_{3} \mathrm{PO}_{4}$, and $0.2 \%$ 4-methyl valerate) and frozen until analysis for $\mathrm{NH}_{3}-\mathrm{N}$ and VFA concentrations, respectively. A third aliquot was analyzed in triplicate for total $\mathrm{N}$ analysis. Three $200-\mathrm{mL}$ portions of each composited sample were lyophilized, ground to pass a 1-mm screen prior to analysis and used for DM, ash, NDF, ADF, and purine bases.

Bacteria were isolated from fermenter flasks on the last day of sampling. Solid phase bacteria were dislodged by adding $100 \mathrm{~mL} \mathrm{2 \%}$ methylcellulose and mixed at $300 \mathrm{rpm}$ for 1 hour at $37^{\circ} \mathrm{C}$, after which fermenter flasks were kept at $4^{\circ} \mathrm{C}$ for 24 hours (Whitehouse et al. 1994). Vessel content was stirred for 1 hour at room temperature before being strained through 2 layers of cheesecloth. Additional bacteria were recovered from the solid fraction by washing with $300 \mathrm{~mL} 0.85 \%$ (wt./vol.) saline solution at room temperature. Bacterial cells were isolated by differential centrifugation at $1000 \times \mathrm{g}$ for 15 minutes to eliminate feed particles, and at $20000 \times \mathrm{g}$ for 20 minutes to isolate the bacterial pellet. Pellets were rinsed with saline solution and recentrifuged at $20000 \times \mathrm{g}$ for 20 minutes. After further rinsing with distilled water to prevent contamination of bacteria with ash, bacterial cells were lyophilized and analyzed for DM, ash, $\mathrm{N}$, and purine concentrations.

\section{Chemical Analyses and Calculations}

Effluent DM was calculated by lyophilizing $200-\mathrm{mL}$ aliquots in triplicate with subsequent drying at $103^{\circ} \mathrm{C}$ in a forced air oven for 24 hours. Dry matter content of diets and bacterial samples were determined by drying samples for 24 hours in a $103^{\circ} \mathrm{C}$ forced air oven. Dry samples were ashed according to the Association of Official Analytical Chemists (AOAC 1990) using a muffle furnace. Dietary ether extract was determined according to AOAC (1990). Total $\mathrm{N}$ in feed, effluents, and bacterial samples were determined by the Kjeldahl method (AOAC 1990). The $\mathrm{NH}_{3}-\mathrm{N}$ was determined by spectrophotometry (Chaney and Marbach 1962). The NDF and ADF concentrations in feed and effluents were determined sequentially using alpha-amylase and sodium sulphate (Van Soest et al. 1991). The VFA concentrations in deproteinised effluent fluid samples were determined by gas chromatography (GLC, Hewlett Packard, Palo Alto, CA) using 4-methylvaleric acid as internal standard (Jouany 1982) and a polyethylene glycol TPA-treated capillary column (BP21, SGE Europe Ltd, Milton Keynes, UK). Effluent and bacterial cells were analyzed for purine (adenine and guanine) content by HPLC (Hewlett Packard) using allopurinol as internal standard (Balcells et al. 1992). Digestibility of DM, NFD and ADF, and flows of total, ammonia, non-ammonia, microbial, and dietary nitrogen were calculated as described by Stern and Hoover (1990).

\section{Statistical Analyses}

Results from VFA and $\mathrm{NH}_{3}-\mathrm{N}$ concentration during the daily sampling were analyzed using the PROC MIXED procedure of SAS (SAS Institute Inc, Cary, NC) for repeated measures (Littell et al. 1996). The model accounted for the effects of inoculum type and days and the interaction of inoculum type $x$

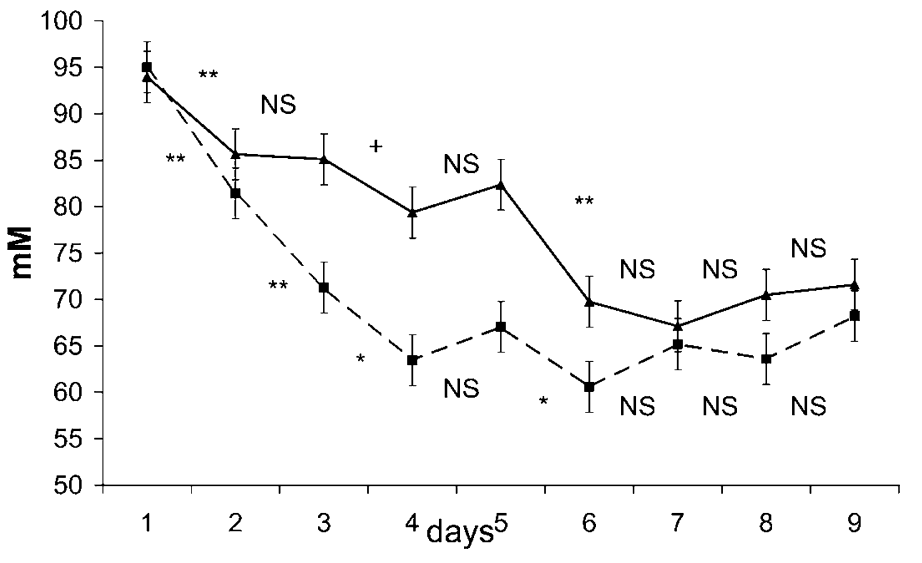

Figure 1. Total volatile fatty acid concentration (mM) in cattle ( $\square)$ and chamois $(\mathbf{\Delta})$ between day 1 and day 9 of the experiment in samples taken 2 hours after the morning feeding. Statistics indicate if the values of 2 consecutive days in each inoculum are statistically different (NS indicates $P>0.1 ;+, P<0.1 ;{ }^{*}, P<0.05$; and $\left.{ }^{*}, P<0.01\right)$. The bars show the standard error of the mean.

days. The fermenter was included in the statistical analysis as a random effect. The VFA concentrations and $\mathrm{N}$ fractions were subjected to three covariance structures: compound symmetric, autoregressive order one, and unstructured covariance. The covariance structure that yielded the smallest Schwarz's Bayesian criterion and closest to Likelihood value was considered to be the most suitable analysis. For the present study, autoregressive structure was chosen. The residual maximum likelihood was used as a method of estimation. The least square means of fixed effects (LSMEANS) were used when analysis of variance indicated significant differences. The degrees of freedom were 1 for inoculum type, 8 for days, and 8 for the interaction inoculum type $\times$ days, with a total degrees of freedom of 53 for all the variables studied with PROC MIXED. Data obtained from the sampling period in relation to DM, NDF and ADF digestibilities, VFA, and nitrogen metabolism were compared between innocula using the PROC TTEST procedure of SAS. In this case, the number of degrees of freedom was 2 for all these variables.

\section{RESULTS}

\section{Daily Sampling}

Total VFA concentrations in each inocula decreased $(P<$ 0.001) during the adaptation period, remaining relatively constant thereafter (Fig. 1). Total VFA concentrations were greater for chamois inoculum from day 3 to day $6(P<0.05)$, with differences disappearing thereafter. Molar proportions of acetate, propionate, and butyrate are shown in Figures 2a, 2b, and 2c. Molar proportion of acetate decreased (Fig. 2a; $P<$ 0.001 ) and molar proportion of butyrate increased (Fig. 2c; $P<$ 0.01 ) from day 1 to day 9 . In contrast, the molar proportion of propionate was more constant throughout the adaptation and sampling periods (Fig. 2b). The day to day molar proportion of propionate was greater $(P<0.01)$ in chamois than in cattle while the molar proportion of butyrate was lower $(P<0.05)$ in chamois when compared to cattle. Molar proportion of acetate 

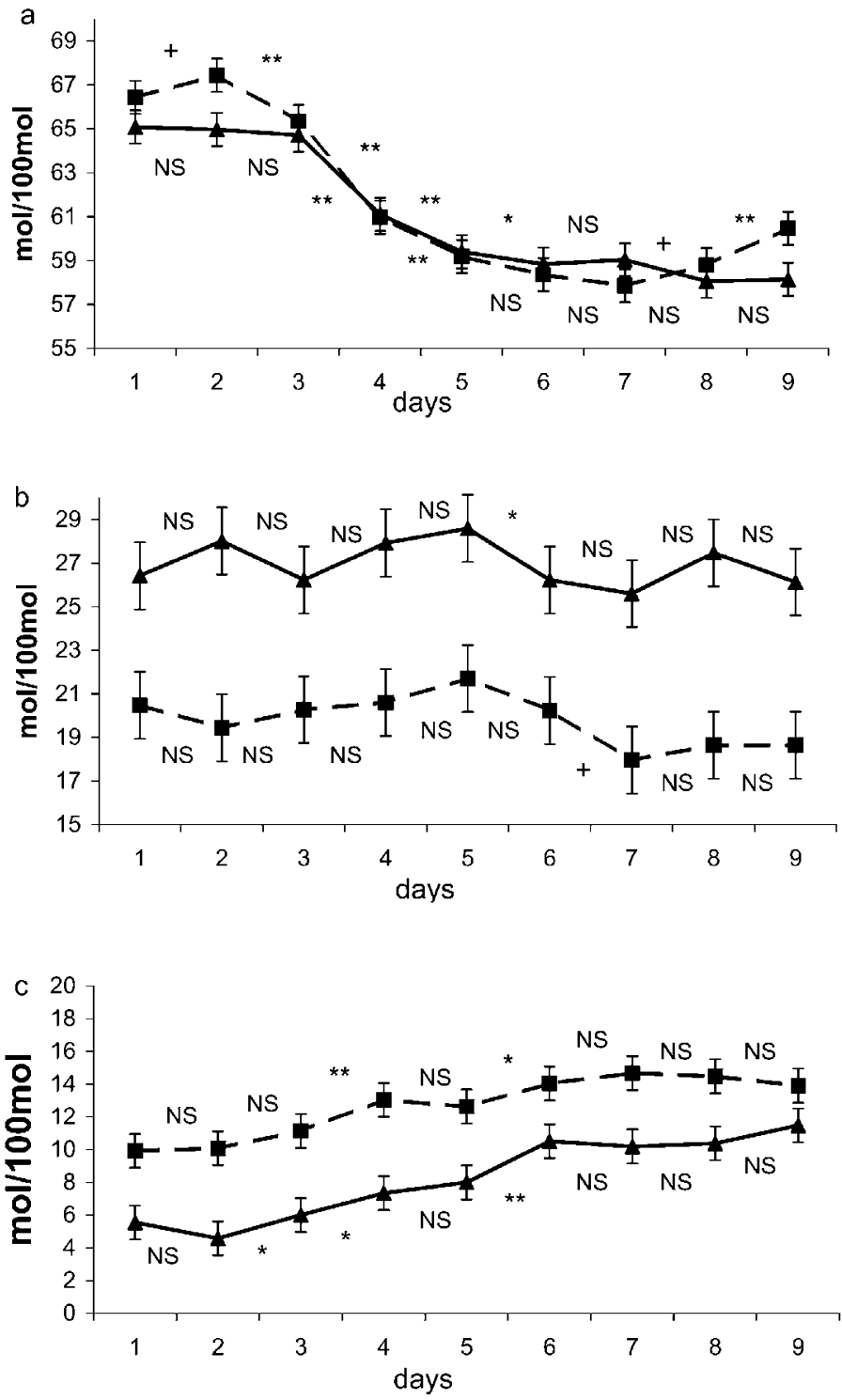

Figure 2. Proportion (mol/100 mol) of acetate (2a), propionate (2b), and butyrate (2c) in cattle $(\boldsymbol{\square})$ and chamois $(\boldsymbol{\Delta})$ between day 1 and day 9 of the experiment in samples taken 2 hours after the morning feeding. Statistics indicate if the values of 2 consecutive days in each inoculum are statistically different (NS indicates $P>0.10$;,$+ P<0.10$; ${ }^{*}, P<$ 0.05 ; and ${ }^{* *}, P<0.01$ ). The bars show the standard error of the mean.

did not differ $(P>0.10)$ between chamois and cattle, except for days 2 and $9(P<0.05)$.

Total $\mathrm{NH}_{3}-\mathrm{N}$ concentration $(\mathrm{mg} / 100 \mathrm{~mL}$ ) decreased (Fig. 3; $P<0.01$ ) in the chamois inoculum from 19 at day 1 to 13 at day 9. In the cattle inoculum, no differences were found in total $\mathrm{NH}_{3}-\mathrm{N}$ concentration from day 1 to day 9, although there was a significant fluctuation during the adaptation period, from day 1 to day 5. Thereafter, the $\mathrm{NH}_{3}-\mathrm{N}$ concentration remained constant and averaged $11 \mathrm{mg} / 100 \mathrm{~mL}$. In fact, $\mathrm{NH}_{3}-\mathrm{N}$ concentration was constant in inoculum from both species from day 6 to day 9. Ammonia nitrogen concentration was greater in the chamois inoculum than in cattle throughout the experiment, although the differences were only significant $(P<$ 0.05 ) at days $1,3,5$, and 6 , and tended to be higher at day 8 .

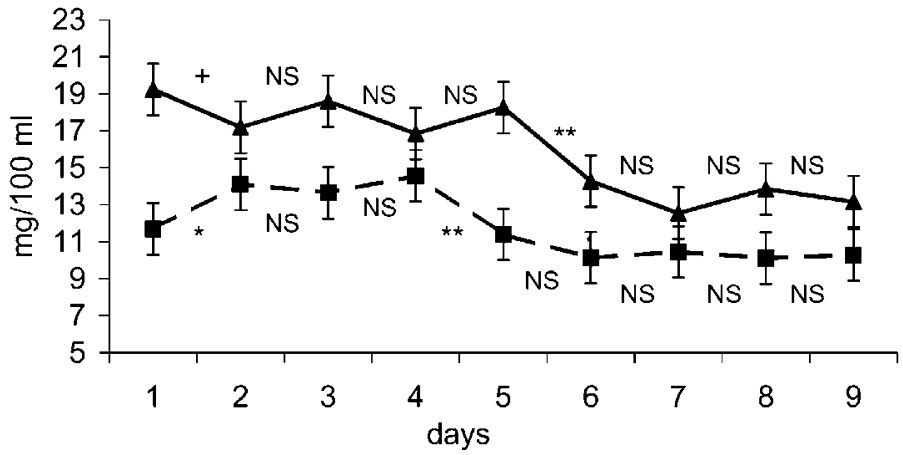

Figure 3. Ammonia nitrogen concentration $(\mathrm{mg} / 100 \mathrm{~mL})$ in cattle (ם) and chamois $(\boldsymbol{\Delta})$ between day 1 and day 9 of the experiment in samples taken 2 hours after the morning feeding. Statistics indicate if the values of 2 consecutive days in each inoculum are statistically different (NS indicates $P>0.10 ;+, P<0.10 ;{ }^{*}, P<0.05$; and $\left.{ }^{* *}, P<0.01\right)$. The bars show the standard error of the mean.

\section{Sampling Period}

Dry matter, NDF and ADF digestibilities were similar $(P>$ 0.10 ) in the 2 inocula, with mean values being $67.8 \%, 50.0 \%$, and $56.0 \%$, respectively (Table 1 ).

Total VFA concentration was similar in the two inocula, with a tendency to be greater in the inoculum of chamois than in cattle inoculum (Table 2; $P<0.10$ ). Molar proportion of propionate was higher in chamois inoculum than in cattle inoculum $(P<$ $0.01)$, while butyrate was lower in chamois than in cattle $(P<$ $0.05)$. Valerate tended $(P<0.10)$ to be greater in chamois inoculum than in cattle inoculum. The molar proportions of isobutyrate, and isovalerate, and the concentration of these 2 branch-chained VFA were lower $(P<0.05, P<0.01$, and $P<$ 0.01 , respectively) in chamois inoculum than in cattle inoculum.

The $\mathrm{NH}_{3}-\mathrm{N}$ concentration $(\mathrm{mg} / 100 \mathrm{~mL})$ was greater in chamois inoculum than in cattle inoculum (Table $3, P<0.01$ ). There were no differences in total or dietary nitrogen flows between inocula. In contrast, the flows of $\mathrm{NH}_{3}-\mathrm{N}$ and nonammonia nitrogen were different $(P<0.01)$, and microbial nitrogen flows tended to be lower in samples from chamois than in cattle samples $(P<0.10)$. Protein degradation was similar in both inocula. Microbial protein synthesis was lower in chamois inoculum when compared to cattle inoculum $(P<$ $0.05)$ and efficiency of microbial protein synthesis tended to be lower in chamois than in cattle $(P<0.10)$.

\section{DISCUSSION}

The continuous fermentation in vitro system used in the present experiment allowed the control of diet, feeding frequency, passage rate, and fermentation conditions, the inoculum being the only factor that differed between the 2 experimental treatments. An in vivo study was rejected as it would have caused stress in the animals as a result of capture and housing. The present study was made with only one individual of each species because of the difficulty to obtain a chamois donor. We acknowledge that ruminal activity can vary both between animals and from day to day in the same animal and that the results presented here should be interpreted taking this limitation into consideration. 
Table 1. Digestibility of dry matter (DM), neutral detergent fiber (NDF) and acid detergent fiber (ADF) in chamois and cattle.

\begin{tabular}{lccccc}
\hline Item & Chamois & SE $^{1}$ & Cattle & SE & $P$ value \\
\hline DM digestibility (\%) & 64.8 & 1.49 & 70.8 & 3.69 & 0.882 \\
NDF digestibility (\%) & 51.8 & 1.44 & 48.1 & 2.10 & 0.213 \\
ADF digestibility (\%) & 56.2 & 1.46 & 55.8 & 2.06 & 0.874 \\
\hline
\end{tabular}

${ }^{1} \mathrm{SE}$ indicates standard error of the mean.

Steady-state conditions were achieved in both treatments from day 6 of the experimental period, as reflected in total VFA and $\mathrm{NH}_{3}-\mathrm{N}$ concentrations. This observation is in accordance with other results obtained in our laboratory (Cardozo et al. 2004) with the same in vitro system and in other studies working with RUSITEC, a semi-continuous fermenter (Czerkawski and Breckenridge 1977). It may therefore be concluded that a 6-day adaptation period before sampling is necessary for chamois and cattle microbial inocula.

Dry matter and fiber digestibility in intermediate feeders is, typically, lower than that observed for grazing ruminants (Arman and Hopcraft 1975; Milne et al. 1978). Usually, this lower digestibility has been associated with a greater ruminal or total tract passage rate. However, in other studies, comparisons between goats, an intermediate eater, and sheep, a grazer, have produced differing results. Fiber and DM digestibilities have been found to be similar in goats and sheep (Jones et al. 1972), higher in goats than in sheep (Gihad 1976) or diet dependent, with digestibilities being similar in a medium quality roughage and even higher in goats than in sheep in a low quality diet (Huston et al. 1986; Masson et al. 1986). In these studies, the relationship between digestibility and rate of passage was also confirmed, being inversely related. In the current experiment, with a predetermined identical rate of passage and with a good quality diet, DM and fiber digestibilities were not different, indicating that the selected microbial populations in the present experiment had the same capacity to digest food in chamois and cattle.

Total VFA concentration was within the range proposed by France and Siddons (1993), and was not different between inocula, in accordance with the similar DM and fiber digestibility. In contrast, there were differences between chamois and cattle inocula in individual VFA proportions. Propionate proportions were greater in chamois than in cattle, while butyrate and branch chained VFA were greater for cattle inoculum. One possible explanation for the greater proportion of propionate in chamois inoculum would be related to the predominance of amylolytic bacteria in concentrate selectors and intermediate feeders, in accordance with Hofmann (1985), as it is known that these bacteria produce greater proportions of propionate (France and Siddons 1993). In this case, it is possible that the amylolytic population in the fermenters after 6 days of adaptation was greater in chamois inoculum than in inoculum of cattle. This would be in accordance with the expected differences in vivo.

Nitrogen utilization by microbial populations in chamois and cattle inocula differed. Ammonia concentrations were within the ranges proposed by Satter and Slyter (1974) for optimal microbial protein synthesis, with concentration being greater in chamois inoculum than in cattle. Greater concentrations of
Table 2. Total volatile fatty acids (VFA) concentration and fermentation profile in chamois and cattle.

\begin{tabular}{lccccc}
\hline Item & Chamois & $\mathrm{SE}^{1}$ & Cattle & $\mathrm{SE}$ & $P$ value \\
\hline Total VFA $(\mathrm{mM})$ & 61.6 & 1.43 & 56.1 & 1.44 & 0.055 \\
Branch-chained VFA $(\mathrm{mM})^{2}$ & 0.18 & 0.02 & 3.28 & 0.22 & 0.005 \\
Individual VFA $(\mathrm{mol} / 100 \mathrm{~mol})$ & & & & & \\
$\quad$ Acetate & 60.3 & 0.32 & 59.7 & 0.19 & 0.175 \\
$\quad$ Propionate & 25.8 & 1.52 & 17.9 & 0.42 & 0.007 \\
$\quad$ Butyrate & 9.9 & 1.06 & 13.8 & 0.37 & 0.025 \\
Valerate & 3.72 & 0.120 & 3.42 & 0.040 & 0.078 \\
$\quad$ Isobutyrate & 0.23 & 0.034 & 0.38 & 0.009 & 0.049 \\
Isovalerate & 0.07 & 0.019 & 4.89 & 0.460 & 0.009 \\
Acetate:propionate ratio & 2.36 & 0.158 & 3.35 & 0.070 & 0.005 \\
\hline
\end{tabular}

${ }^{1} \mathrm{SE}$ indicates standard error of the mean.

${ }^{2}$ Isobutyrate and Isovalerate.

$\mathrm{NH}_{3}-\mathrm{N}$ have been observed in goats, an intermediate feeder, in comparison to sheep, a grazer (Alrahmoun et al. 1986). These authors stated that the greater ruminal $\mathrm{NH}_{3}-\mathrm{N}$ concentrations were a result of the higher ammonia recycling in goats, but this hypothesis does not apply in the in vitro conditions of the present experiment. Ruminal $\mathrm{NH}_{3}-\mathrm{N}$ concentrations are the result of a balance between protein degradation and microbial protein synthesis, together with the ammonia absorption that does not occur in in vitro conditions. In our experiment, protein degradation was numerically lower in chamois inoculum than in cattle inoculum, but the difference was not significant. Nevertheless, the branch chained VFA were also lower in chamois. Considering that these VFA are the result of branch chained amino acid degradation and are considered to be an indicator of protein degradation, it may be that protein degradation was lower in chamois inoculum. Lower protein degradability in an intermediate feeder agrees with studies where goats were compared with sheep (Molina et al. 2003), probably due to differences in the rate of passage. Microbial protein synthesis was also lower in chamois than in cattle. Moreover, efficiency of

Table 3. Ammonia nitrogen concentration, flows of total, ammonia, non-ammonia, dietary, and microbial nitrogen, protein degradation, microbial synthesis, and efficiency of microbial synthesis in chamois and cattle.

\begin{tabular}{lccccc}
\hline Item & Chamois & $\mathrm{SE}^{1}$ & Cattle & $\mathrm{SE}$ & $P$ value \\
\hline Ammonia nitrogen $(\mathrm{mg} / 100 \mathrm{~mL})$ & 10.6 & 0.35 & 6.7 & 0.29 & 0.001 \\
Nitrogen flows (g/day) & & & & & \\
$\quad$ Total & 1.74 & 0.019 & 1.78 & 0.030 & 0.369 \\
$\quad$ Ammonia nitrogen & 0.33 & 0.010 & 0.21 & 0.010 & 0.003 \\
$\quad$ Non-ammonia & 1.41 & 0.007 & 1.57 & 0.020 & 0.003 \\
$\quad$ Microbial & 0.72 & 0.083 & 0.98 & 0.010 & 0.083 \\
$\quad$ Dietary & 0.70 & 0.082 & 0.60 & 0.030 & 0.252 \\
Protein degradation (\%) & 53.1 & 5.48 & 60.7 & 2.10 & 0.269 \\
Microbial nitrogen & & & & & \\
$\quad \%$ of total nitrogen flow & 41.1 & 4.79 & 55.3 & 1.48 & 0.047 \\
g/kg of DM truly digested & 19.1 & 1.76 & 24.2 & 1.14 & 0.062 \\
\hline
\end{tabular}

${ }^{1} \mathrm{SE}$ indicates standard error of the mean; DM, dry matter. 
microbial protein synthesis tended to be lower in chamois inoculum than in cattle inoculum. Russell et al. (1992) stated that maintenance requirements are greater in amylolytic than in cellulolytic bacteria. Assuming the predominance of amylolytic bacteria in intermediate feeders (Hofmann 1985), efficiency of microbial protein synthesis is likely to be lower in chamois, because their microbial population would have higher maintenance requirements than in cattle.

\section{MANAGEMENT IMPLICATIONS}

Continuous fermentation in vitro system could be a useful tool for studying the ruminal fermentation pattern in species difficult to handle such as Pyrenean chamois. In Spain, this species is an important hunting resource (Alados 1997). Therefore, if included in a management plan, taking rumen inocula from hunted chamois in different physiological states, ages, sexes, and zones could provide important information about the species. Winter severity has been defined as an important factor in the mortality of mountain ungulates such as Pyrenean chamois (Crampe et al. 1997), but supplementation of food in this and preceding seasons could have a positive effect on the body condition of individuals (Saltz 1988). From a management point of view, the continuous fermentation in vitro system could thus be used to test different types of diets as a supplementation source. However, the first step is to have an idea of the ruminal function of this species in natural conditions.

Our hypothesis that in the absence of differences in ruminal conditions, passage rate, and diet, microbial population of a chamois and cattle should show a similar capacity to digest the diet, was confirmed by our results. However, other aspects such as different passage rates, comparisons with other species, etc., should be considered in future studies. In contrast to the similar capacity to digest DM and fiber, and the similar concentration of total VFA, the fermentation profile could be different, with a greater proportion of propionate and lower proportions of butyrate and branch-chained VFA in chamois compared with cattle. Moreover, the efficiency of energy utilization for microbial protein synthesis in both species could be different, resulting in a lower microbial protein synthesis and efficiency of microbial protein synthesis in chamois than in cattle. Further research is needed to confirm these differences or if they could be attributed instead to the inocula collected and diet used.

\section{ACKNOWLEDGMENTS}

The collaboration from the staff of the Cadí-Moixeró Natural Park and the Cadí Hunting Reserve is acknowledged.

\section{LITERATURE CITED}

Alados, C. 1997. Spain. In: D.M. Shackleton [ED.]. Wild sheep and goats and their relatives. Status survey and conservation action plan for caprinae. Gland, Switzerland: IUCN. p 125-130.

Alrahmoun, W. C., C. Masson, and J. L. Tisserand. 1986. Etude comparée de l'activité microbienne dans le rumen chez les caprins et les ovins. II. Effet du niveau azoté et de la nature de la source azotée [In French]. Annales de Zootechnie 35:109-120.

Arman, P., and D. Hopcraft. 1975. Nutritional studies on East African herbivores.
Digestibilities of dry matter, crude fiber and crude protein in antelope, cattle and sheep. British Journal of Nutrition 33:255-264.

Association of Official Analytical Chemists. 1990. Official Methods of Analysis. 15th ed. Arlington, VA: AOAC. 1298 p.

Balcells, J., J. Guarda, J. M. Peiró, and D. S. Parker. 1992. Simultaneous determination of allantoin and oxypurines in biological fluids by high performance liquid chromatography. Journal of Chromatography 575: 153-157.

Cardozo, P. W., S. Calsamiglia, A. Ferret, and C. Kamel. 2004. Effects of natural plant extracts on nitrogen metabolism and fermentation profile in continuous culture. Journal of Animal Science 82:3230-3236.

Catusse, M., R. Corti, J. M. Cugnasse, D. Dubray, P. Gibert, and J. Michallet. 1996. Les Chamois et les isards. In: La Grande Faune de Montagne [In French]. Paris, France: Office national de la chasse and Hatier. p 18-70.

Chaney, A. L., And E. P. Marbach. 1962. Modified reagents for determination of urea and ammonia. Clinical Chemistry 8:130-132.

Crampe, J. P., J. C. Caens, J. L. Dumerc, and D. Pepin. 1997. La masse corporelle comme indicateur de la condition physique hivernale de l'Isard, Rupicapra pyrenaica (Artiodatyla, Bovidae) [In French]. Mammalia 61:73-85.

Czerkawski, J. W., and G. BreCkenridge. 1977. Design and development of a longterm rumen simulation technique (Rusitec). British Journal of Nutrition 38:371-384.

Folch, R. 1981. La vegetació dels Països Catalans [In Catalan]. Barcelona, Spain: Ketres Editora, S. A.

France, J., And R. C. Siddons. 1993. Volatile fatty acid production. In: J. M. Forbes and J. France [EDS.]. Quantitative aspects of ruminant digestion and metabolism. Oxon, United Kingdom: CAB International. p 107-121.

GIHAD, E. A. 1976. Intake, digestibility and nitrogen utilization of tropical natural grass hay by goats and sheep. Journal of Animal Science 43:879-883.

GurRI, F. 1997. Cadí-Moixeró Parc Nacional, Pedraforca Paratge Natural. In: Parcs Naturals de Catalunya [In Catalan]. Barcelona, Spain: Editorial 92. p 62-77.

Hofmann, R. R. 1985. Digestive physiology of the deer. Their morphophysiological specialization and adaptation. In: P. F. Fennessy and K. R. Drew [EDs.]. Biology of deer production. Wellington, New Zealand: The Royal Society of New Zealand, Bulletin 22. p 393-407.

Hofmann, R. R. 1988. Anatomy of the gastrointestinal tract. In: D. C. Church [ed.]. The ruminant animal: Digestive physiology and nutrition. Englewood Cliffs, $\mathrm{NJ}$ : Prentice-Hall. p 14-43.

Hoover, W. H., B. A. Crooker, and C. J. Sniffen. 1976. Effects of differential solidliquid removal rates on protozoa numbers in continuous cultures of rumen contents. Journal of Animal Science 43:528-534.

Huston, J. E., B. S. Rector, W. C. Ellis, and M. L. Allen. 1986. Dynamics of digestion in cattle, sheep, goats and deer. Journal of Animal Science 62: 208-215.

Jones, G. M., R. E. Larsen, A. H. Javed, E. Donefer, and J. M. Gaudreau. 1972. Voluntary intake and nutrient digestibility of forages by goats and sheep. Journal of Animal Science 34:830-838.

JouAny, J. J. 1982. Volatile fatty acids and alcohol determination in digestive contents, silage juice, bacterial cultures and anaerobic fermentor contents. Sciences des Aliments 2:131-144.

Littell, R. C., G. A. Milliken, W. W. Stroup, and R. D. Wolfinger. 1996. SAS system for mixed models. Cary, NC: SAS Institute Inc.

Masson, C., W. Alrahmoun, and J. L. Tisserand. 1986. Etude comparée de la quantité ingérée, de la digestibilité, de l'utilisation de l'azote, du temps moyen de rétention et du comportement alimentaire chez les jeunes caprins et ovins recevant différents régimes [In French]. Annales de Zootechnie 35:49-60.

Milne, J. A., J. C. MacRae, A. M. Spence, and S. Wilson. 1978. A comparison of the voluntary intake and digestion of a range of forages at different times of the year by the sheep and the red deer (Cervus elaphus). British Journal of Nutrition 40:347-357.

Molina, E., D. R. Yáñez, A. Moumen, and A. I. Martín. 2003. Ruminal degradability and in vitro intestinal digestibility of sunflower meal and in vitro digestibility of olive by-products supplemented with urea or sunflower meal: comparison between goats and sheep. Animal Feed Science and Technology 110:3-15. 
Russell, J. B., J. D. O'Connor, D. G. Fox, P. J. Van Soest, and C. J. Sniffen. 1992. A net carbohydrate and protein system for evaluating cattle diets: I. Ruminal fermentation. Journal of Animal Science 70:3551-3561.

SALTZ, D. 1988. Urinary cortisol and urea nitrogen responses to winter stress in mule deer (Odocoileus hemionus) [Ph. D. Thesis]. Fort Collins, C0: Colorado State University. $65 \mathrm{p}$.

SAtTeR, L. D., and L. L. Slyter. 1974. Effect of ammonia concentration on rumen microbial protein production in vitro. British Journal of Nutrition 32: 199-208.

Stern, M. D., AND H. W. Hoover. 1990. The dual flow continuous culture system. In: Proc. Continuous culture fermenters: Frustation or fermentation. Chazy, NY: Northwest ADSA-ASAS regional meeting. p 17-32.

Van Soest, P. J. 1994. Feeding strategies, taxonomy and evolution. In: Nutritional ecology of the ruminant. 2nd ed. Ithaca, NY: Cornell University Press. p 2256.

Van Soest, P. J., J. B. Robertson, and B. A. Lewis. 1991. Methods for dietary fiber, neutral fiber and nonstarch polysacharides in relation to animal nutrition. Journal of Dairy Science 74:3588-3597.

Weller, R. A., and A. F. Pilgrim. 1974. Passage of protozoa and volatile fatty acids from the rumen of sheep and from a continuous in vitro fermentation system. British Journal of Nutrition 32:341-351.

Whitehouse, N. L., V. M. Olson, C. G. Shwab, W. R. Chesbro, K. D. Cunningham, and T. LYKos. 1994. Improved techniques for dissociating particle-associated mixed ruminal microorganisms from ruminal digesta solids. Journal of Animal Science 72:1335-1343. 